\title{
Yeast cells as a feed supplement for cattle 1. Liquid viable yeast cultures for calves
}

\author{
J.A. Strzetelski, Teresa Ernest, Julita Maciejewicz-Ryś, \\ Katarzyna Maciaszek, J. Kowalczyk* and Elżbieta Lipiarska
}

\author{
Research Institute of Animal Production, \\ Department of Animal Nutrition and Physiology \\ 32-083 Balice, Poland \\ * The Kielanowski Institute of Animal Physiology and Nutrition, \\ Polish Academy of Sciences \\ 05-110 Jablonna, Poland
}

(Received 6 February 1995; accepted 22 August 1995)

\begin{abstract}
An experiment lasting 73 days was carried out on 40 Black-and-White Lowland 7-day-old calves divided into 5 groups of 8 . The animals received $8 \mathrm{~kg}$ of whole milk daily for 5 weeks, $6 \mathrm{~kg}$ in the 6 th and $3 \mathrm{~kg}$ in 7 th week with free access to concentrate mixture and meadow hay. After 7 weeks of the experiment the calves were fed only concentrate to appetite and $0.3-0.4 \mathrm{~kg}$ of meadow hay. This basic control diet was supplemented with wort without yeast and in the experimental groups with liquid cultures of the yeast, Saccharomyces cerevisiae 1026 or Saccharomyces carlsbergensis of the brewery strain SK-1, BS-Bratislava or wine strain T-81. All strains of yeast significantly stimulated amylolytic and proteolytic activity of the digesta in the duodenum, small intestine and ileum but not in the abomasum. Body weight gains of calves fed diets supplemented with SK-1 and B-Bratislava yeast were higher than in control or in groups supplemented with the other two yeast strains.
\end{abstract}

KEY WORDS: calf performance, yeast, enzymatic activity, amino acid profile

\section{INTRODUCTION}

Natural fungal additives containing viable cells have become of interest in ruminant nutrition (Pusztai et al., 1990; Williams and Newbold, 1990). It was reported that such additives as fungal cultures based on Saccharomyces cerevisiae 1026 and Aspergillus oryzae had an advantageous effect on calf and 
mature ruminant performance, protein and carbohydrate metabolism in the digestive tract and on animal product quality (Williams, 1989; Williams and Newbold, 1990; Edwards, 1991; Wallace and Newbold, 1992; Alonzo et al.,1993; Caton et al., 1993; Shievert and Shaver, 1993; Skórko-Sajko, 1993). However, information is lacking on fungal culture activity in the ruminant digestive tract, particularly beyond the rumen, and on the beneficial effect of new species and strains on digestion and utilization of nutrients.

The objective of this study was to compare different liquid cultures of Saccharomyces carlsbergensis and Saccharomyces cerevisiae 1026 on the performance, enzyme activity and amino acid profile of the intestinal digesta of calves.

\section{MATERIAL AND METHODS}

\section{Animals and experimental design}

At the age of 7 days, forty Black-and-While Lowland calves were divided into 5 groups of 8 ( 4 males and 4 females in each) allotted to the groups sequentially, according to calving order. The animals were kept tied in straw-bedded pens and fed individually at controlled intake and permanent access to water.

New-born calves were fed $2 \mathrm{~kg}$ of colostrum on the first day between 2 and $6 \mathrm{~h}$ of life, increasing with age to $6 \mathrm{~kg} /$ day fed in 3 portions until day 7 . Subsequently, as the experimental period lasting 73 days started, whole milk was given to all the calves at the rate of $8 \mathrm{~kg}$ for 5 weeks; $6 \mathrm{~kg}$ in the $6 \mathrm{th}$ and $3 \mathrm{~kg}$ in the 7 th week with free access to concentrate mixture and meadow hay. After week 7 the calves were fed only concentrate to appetite and $0.3-0.4 \mathrm{~kg}$ hay according to the INRA (1988) system. The concentrate mixture consisted of $(\%)$ : ground barley, 50; ground wheat, 14; soyabean oilmeal, 21; wheat bran, 13 and mineral mixture ${ }^{1}, 2$.

The control group (C) was given additionally $200 \mathrm{ml} /$ day of wort without yeast with milk or in the final 24 days - with concentrate. Calves of the experimental groups received the same amount of wort containing the respective yeast culture:

- Saccharomyces cerevisiae strain 1026 (Group - Yp);

- Saccharomyces carlsbergensis brewery strain SK-1 (Group - S);

- Saccharomyces carlsbergensis brewery strain BS-Bratislava (Group - B)

- wine yeast strain T-81 (Group - T).

\footnotetext{
${ }^{1}$ Mineral mixture composition, \%: Bovimix 50 (commercial mineral preparation), common salt 15, limestonc 25 and $\mathrm{CaHPO}_{4} 10$. One kg of mixture contained (g): $172 \mathrm{Ca} ; 73 \mathrm{P} ; 57 \mathrm{Na} ; 88 \mathrm{Cl}$; $19.3 \mathrm{Mg} ; 1.4 \mathrm{Fe} ; 0.75 \mathrm{Cu} ; 1.45 \mathrm{Mn} ; 0.03 \mathrm{Co}$ and $1.3 \mathrm{Zn}$
} 
All male calves were sacrificed on the last day of the experiment $3 \mathrm{~h}$ after feeding and total content of the abomasum (A), duodenum (D), small intestine (J) and ileum (I) was collected and representative samples were taken, stored at $-25^{\circ} \mathrm{C}$ and freeze-dried before analyzing.

\section{Yeast culture production}

Agar cultures of Saccharomyces carlsbergensis (strain SK-1; BS-Bratislava or T-81) were obtained from the Institute of Biotechnology of the Agriculture and Food Industry in Warsaw. Saccharomyces cerevisiae strain 1026 was isolated using a plate method on Difco malt agar from Yea-Sacc yeast supplied by Alltech Biotechnology Center (USA). The yeasts were cultivated on $12^{\circ} \mathrm{Blg}$ crude malt wort without hops. The portioned wort was stored in plastic bags at $-15^{\circ} \mathrm{C}$. Portions of wort were thawed, warmed to $25^{\circ} \mathrm{C}$ and inoculated with a stock culture $(4 \%)$ and fed after $48 \mathrm{~h}$ of incubation at $25^{\circ} \mathrm{C}$.

Stock cultures of yeast strains were obtained by inoculation of wort, previously sterilized for $30 \mathrm{~min}$ in a boiling water bath for 3 consecutive days, from agar slants and incubation for $48 \mathrm{~h}$ at $25^{\circ} \mathrm{C}$. The obtained cultures were refreshed each week by transferring $4 \%$ of strains to fresh sterilized wort, incubating for $48 \mathrm{~h}$ and storing in a refrigerator until the next transfer.

\section{Chemical analysis}

The density of yeast cultures given to calves was determined once a week by counting in a Burker chamber the number of yeast cells in samples fixed in formalin-glycerol. The purity of yeast cultures was controlled once a month by malt agar inoculation on Petri dishes and incubation at $25^{\circ} \mathrm{C}$ for $72 \mathrm{~h}$.

Proximate analysis of feeds and nitrogen content in freeze-dried digesta samples was carried out using conventional methods (AOAC, 1975). The nutritive value of feeds was cstimated according to the INRA (1988) system using Polish computer software INWAR 1.0 (1993). Concentrate composition was established with INRAtion 2.03 (1993) software.

Digesta alpha-amylase activity was estimated according to the Bernfeld method (1955), proteolytic activity according to Kakade et al. (1969). Amino acid proportions in yeast and hydrolyzed digesta were analyzed using a Carl Erba 3A-29 analyzer. 


\section{Statistical analysis}

The obtained data were subjected to one or two factorial variance analyses using Statgraphics Plus 6.0 software (1992).

\section{RESULTS}

The average density of yeast culture ( $\mathrm{n} \times 10^{6}$ cells $/ \mathrm{ml}$ ) was: 104.6 - for Saccharomyces cerevisiae 1026 and 100.8; 210.4; 156.9 for Saccharomyces carlsbergensis strains SK-1, BS-Bratislava and T-81, respectively. Control of yeast culture purity showed that all cultures were satisfactorily pure and bacterial cells were found only sporadically.

The chemical composition and nutritive value of the whole milk, concentrate and meadow hay are shown in Table 1.

The average consumption of concentrate mixture during the experimental period did not differ among the groups and equalled 59 in group $C ; 63$ in group $\mathrm{S}$ and $61 \mathrm{~kg}$ per calf in the remaining two groups $(\mathrm{P}>0.05)$. Average daily intake of concentrate mixture was $0.82 \pm 0.03 \mathrm{~kg}$; crude protein $-300 \pm 4 \mathrm{~g}$; PDI $-241 \pm 3 \mathrm{~g} ; \mathrm{UFL}-2.13 \pm 0.03 \mathrm{~g}$ and $24.33 \pm 0.22 \mathrm{MJ}$ ME. Daily weight gain of calves (Table 2) in group S, receiving SK-1 yeast culture, was higher than in groups $C, Y p$ and $T(P \leqslant 0.05)$ with slightly better, but not significantly, crude protein and concentrate utilization per $1 \mathrm{~kg}$ body weight gain. Average daily weight gain was about $8 \%$ higher and nutrient utilization $6 \%$ higher in group $\mathrm{S}$ compared with the control group C. Calves of group B gained more and utilized nutrients about $4 \%$ better as compared with group C.

TABLE 1

Chemical composition (\%) and nutritive value of feeds

\begin{tabular}{lcccccc}
\hline Feeds & $\begin{array}{c}\text { Dry } \\
\text { matter }\end{array}$ & $\begin{array}{c}\text { Crude } \\
\text { protein }\end{array}$ & $\begin{array}{c}\text { Ether } \\
\text { extract }\end{array}$ & $\begin{array}{c}\text { Crude } \\
\text { fibre }\end{array}$ & $\begin{array}{c}\text { N-free } \\
\text { extractives }\end{array}$ & Ash \\
\hline Whole milk & 12.13 & 2.90 & 3.81 & - & 4.67 & 0.75 \\
Ground barley & 87.10 & 8.01 & 2.08 & 4.45 & 70.56 & 2.00 \\
Ground wheat & 87.40 & 9.70 & 1.76 & 2.64 & 71.44 & 1.86 \\
Soyabcan oilmeal & 87.30 & 40.77 & 2.32 & 6.28 & 30.68 & 7.25 \\
Wheat bran & 87.20 & 13.25 & 3.32 & 6.98 & 59.03 & 4.62 \\
Concentrate mixture & 87.20 & 15.70 & 2.20 & 4.71 & 59.45 & 5.14 \\
Mcadow hay & 85.90 & 11.46 & 2.52 & 25.03 & 42.81 & 4.08 \\
\hline
\end{tabular}

according to INRA system (PAN-INRA, 1993) content in $1 \mathrm{~kg} \mathrm{DM}$ of meadow hay $83 \mathrm{~g} \mathrm{PDI}$ $(\mathrm{PDIN}=\mathrm{PDIE})$ and $0.73 \mathrm{UFL}$; concentrate mixture $-124 \mathrm{~g}$ PDI $(\mathrm{PDIN}=\mathrm{PDIE})$ and $1.20 \mathrm{UFL}$; whole milk $-140 \mathrm{~g}$ PDI $=$ PDIE $($ PDIN $=165)$ 
薯

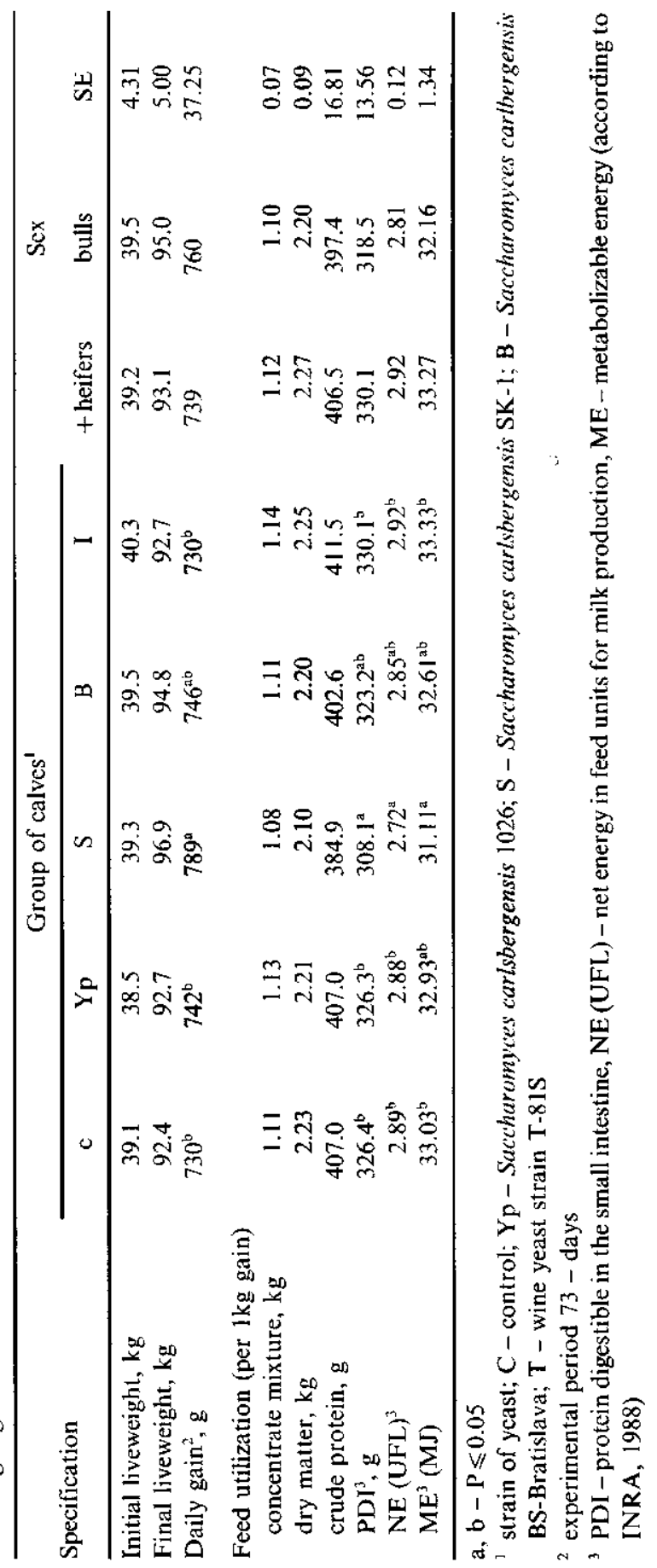


TABLE 3

Amylolytic (P) and proteolytic activity (P), crude protein (CP) content and total amino acid (AA) profile in digesta of total intestine and parts of digestive tract in calves fed different strains of yeast

\begin{tabular}{|c|c|c|c|c|}
\hline \multirow{2}{*}{ Group } & \multicolumn{2}{|c|}{ Activity } & \multicolumn{2}{|c|}{ Percent of DM } \\
\hline & A & $\mathbf{P}$ & crude protein & total amino acid \\
\hline \multicolumn{5}{|c|}{ Bulked sample of digesta of abomasum, duodenum, small intestine and ileum } \\
\hline Control & $617^{\wedge a}$ & $2346^{\mathrm{a}}$ & 37.7 & $31.9^{\mathrm{ab}}$ \\
\hline Yp 1026 & $720^{\mathrm{a}}$ & $2950^{\mathrm{ab}}$ & 36.9 & $30.1^{\text {ab }}$ \\
\hline SK-1 & $1017^{\mathrm{Aa}}$ & $3380^{\mathrm{ab}}$ & 37.2 & $29.1^{\mathrm{a}}$ \\
\hline BS & $1780^{\mathrm{Rh}}$ & $3486^{\mathrm{b}}$ & 38.3 & $31.9^{\mathrm{ab}}$ \\
\hline T-81 & $961^{\mathrm{Aa}}$ & $2702^{\mathrm{ab}}$ & 41.5 & $35.5^{\mathrm{b}}$ \\
\hline \multicolumn{5}{|c|}{ Digesta from resecptive parts of digestive tract } \\
\hline Abomasum & $118^{\mathrm{Aa}}$ & $360^{\mathrm{Aa}}$ & $13.1^{\text {Aa }}$ & $9.8^{\mathrm{Aa}}$ \\
\hline Duodenum & $1149^{8 b}$ & $2966^{\mathrm{Bb}}$ & $53.4^{\mathrm{Cc}}$ & $46.3^{\mathrm{C} c}$ \\
\hline Small intestine & $1697^{\mathrm{Bb}}$ & $4536^{\mathrm{Ce}}$ & $59.5^{\mathrm{Cc}}$ & $50.6^{\mathrm{Cc}}$ \\
\hline Ileum & $1112^{\mathrm{Bb}}$ & $4030^{\mathrm{cc}}$ & $25.4^{\mathrm{Bb}}$ & $20.1^{\mathrm{Rb}}$ \\
\hline SE & 422 & 1121 & 5.1 & 5.8 \\
\hline Interaction & $* *$ & $* *$ & NS & NS \\
\hline
\end{tabular}

$\Delta-1$ unit activity $=$ absorbance increase by 0.01 at $550 \mathrm{~nm}(\mathrm{~A})$ or $280 \mathrm{~nm}(\mathrm{P})$ wave length in both tests $a b c-P \leqslant 0.05 ; A B C-P \leqslant 0.01$

Average amylolytic and proteolytic activities in whole digestive tract contents were higher in calves fed yeast than in the control group, but significant differences were demonstrated only for group $\mathbf{B}(\mathbf{P} \leqslant 0.01)$ for amylolytic activity and $(\mathrm{P} \leqslant 0.05)$ for proteolytic activity (Table 3$)$.

Enzymatic activity differed along the digestive tract and reached the highest values in digesta from the small intestine (J) and ileum (I), lower in the duodenum (D) and the smallest in the abomasum (A) $(\mathrm{P} \leqslant 0.01)$. Interaction between yeast strain and enzymatic activity in digesta from different part of digestive tract was significant $(\mathrm{P} \leqslant 0.01)$.

Average crude protein content in the dry matter of bulked digesta of whole intestines did not differ significantly among treatments, including the control group $(\mathbf{P}>0.05)$ but reached the highest value in the duodenum and small intestine, the lowest values were obtained in the abomasum (Table 3). Total amino acid content in dry matter of bulked samples from the digestive tract was the highest in animals of group $\mathrm{T}$ and the lowest in group $\mathrm{S}(\mathrm{P} \leqslant 0.05)$.

Crude protein and total amino acid were the lowest in abomasal digesta dry matter (Table 3) but increased in the duodenum and small intestine $(P \leqslant 0.01)$ while declining again in ileal digesta $(P \leqslant 0.01)$. The amino acid proportion was similar in all of the used yeast cultures. 


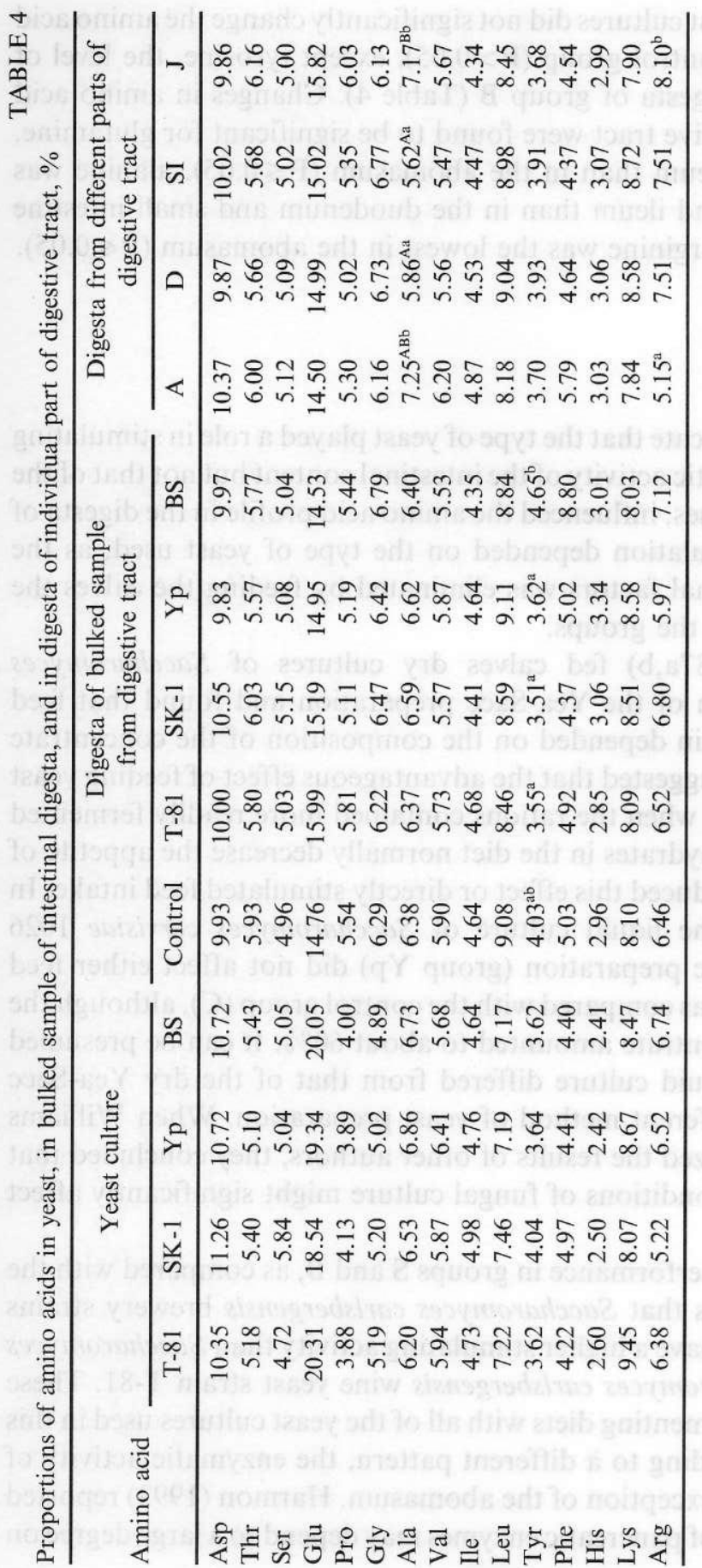


Feeding rations with yeast cultures did not significantly change the amino acid profile in relation to the control group $(P>0.05)$, except tyrosine, the level of which was higher in the digesta of group $B$ (Table 4). Changes in amino acid proportion along the digestive tract were found to be significant for glutamine, which was higher in the ileum than in the abomasum $(P \leqslant 0.05)$, alanine was higher in the abomasum and ileum than in the duodenum and small intestine $(P \leqslant 0.05$ or $P \leqslant 0.01)$ and arginine was the lowest in the abomasum $(P \leqslant 0.05)$.

\section{DISCUSSION}

The obtained results indicate that the type of yeast played a role in stimulating the amylolytic and proteolytic activity of the intestinal content but not that of the abomasum and, in some cases, influenced the amino acid profile in the digesta of calves. The degree of stimulation depended on the type of yeast used, as the influence of other nutritional factors was eliminated by feeding the calves the same basal ration in all of the groups.

Fallon and Harte $(1987 \mathrm{a}, \mathrm{b})$ fed calves dry cultures of Saccharomyces cerevisiae 1026 in the form of the Yea-Sacc preparation and found that feed intake and body weight gain depended on the composition of the concentrate mixture. Williams (1988) suggested that the advantageous effect of feeding yeast to calves was better visible when the rations contained more readily fermented carbohydrate. Such carbohydrates in the diet normally decrease the appetite of animals, but yeast either reduced this cffect or directly stimulated feed intake. In the present experiment, the liquid culture of Saccharomyces cervisiae 1026 isolated from the Yea-Sacc preparation (group Yp) did not affect either feed intake or body weight gain as compared with the control group (C), although the starch content in the concentrate amounted to about $60 \%$. It can be presumed that the activity of the liquid culture differed from that of the dry Yea-Sacc preparation duc to the different method of yeast preparation. When Williams and Newbold (1990) analyzed the results of other authors, they concluded that changing the cultivation conditions of fungal culture might significantly affect their metabolic activity.

The slightly better calf performance in groups $\mathrm{S}$ and $\mathrm{B}$, as compared with the remaining groups, suggests that Saccharomyces carlsbergensis brewery strains (SK-1 and BS-Bratislava) have a higher stimulating activity than Saccharomyces cervisiae 1026 and Saccharomyces carlsbergensis wine yeast strain T-81. These results indicate that supplementing diets with all of the yeast cultures used in this study increased, but according to a different pattern, the enzymatic activity of intestinal digesta with the exception of the abomasum. Harmon (1993) reported that secretion and activity of pancreatic enzymes may depend to a large degree on 
the quantity, quality and proportion of nutrients in the diet; may be the yeast included in the diets affect this activity. Pusztai ct al. (1990) suggest that digestion and absorption of nutrients are related to chemical probiosis which is defined as the interaction between feed components, physiological function of the intestine and microbiological spectrum in the digestive tract. Williams (1989) and Williams and Newbold, (1990) demonstrated that, after feeding animals Saccharomyces cerevisiae 1026 , live yeast cells can be found in the duodenum or small intestine, indicating extraruminal influence of yeast on the digestive processes. The interaction found between type of yeast culture fed and digesta enzymatic activity, depending on the part of digestive tract, suggests that the effectiveness of the yeast additive in our experiment was related to the function of the given segment of the digestive tract (Garvie et al., 1984; Barrow et al., 1989).

The lowest proportion of crude protein in dry malter of abomasal digesta could be explained by the relatively high content of nitrogen frec components in this part of the digestive tract. Their higher rate of digestion in the initial parts of the intestine than the rate of protein absorption leads to a higher apparent proportion of protein in digesta of the duodenum and small intestine. The digestion rate of protein in the ileum prevails, leading to a relatively lower protein content than in the small intestine in the digesta.

The lack of changes in the amino acid profile of the digesta content between the control and experimental groups, excluding tyrosine, suggests that adding yeast to the diet of calves did not influence the amino acid composition of the digesta.

In conclusion, it could be said that viable yeast fed with rations to calves affected the amylolytic and proteolytic activity of the digesta. Viable Saccharomyces carlsbergensis brewery strains SK-1 and BS-Bratislava used as a supplement to the diet for calves could be of practical significance as they resulted in higher daily body gain of animals in comparison with the control group or those supplemented with Saccharomyces carlsbergensis or wine strain T-81 or Saccharomyces cerevisiae 1026.

\section{REFERENCES}

Alonzo R., Mirales E., Killen J., 1993. Effect of viable yeast culture (Yea-Sacc 1026) on milk yield of Holstein cows and on weight gain of calves at 90 days. J. Anim. Sci. 71, Suppl. 1, 289

AOAC, 1975. Association of an Official Analytical Chemists. Official Methods of Analysis, 12th Ed., Washington DC:

Barrow P.A, Brooker B.E., Fullcr R., Newport M.J., 1980. The attachement of bacteria to the gastric epithelium of the pig and its importance in the microecology of the intestine. J. Appl. Bacteriol. $48,147-154$

Bernfeld P., 1955. In: S.P. Colowick, N.O. Kaplan (Editors). Methods in Enzymology. Academic Press, New York. I, pp. 149-150 
Caton J.S., Erickson D.O., Carcy D.A., Ulmer D.L., 1993. Influence of Aspergillus oryzae fermentation extract on forage intake, site of digestion, in situ degradability and duodenal amino acid flow in steers grazing cool-season pasture. J. Anim. Sci. 71, 779-787

Edwards E., Mutsvangwa T., Topps J.H., Paterson G.F.M., 1990. The cffects of supplemental yeast culture (Yea-Sacc) on patterns of rumen fermentation and growth performance of intensively fed bulls. Anim. Prod. 50, 579 (abstr.)

Edwards I.F., 1991. Practical uses of yeast culture in beef production: Insight into its mode of action. In: Biotechnology in the Feed Industry, Ailtech Technical Publications, Nicholasville, Kentucky, pp. 51-64

Erasmus L.J., 1991. The importance of duodenal amino acid profiles for dairy cows and significance of changes in these profiles following the use of Yea-Sacc 1026. In: T.P. Lyons (Editor). Biotechnology in the Fecd Industry. Alltech Technical Publications, Nicholasville, Kentucky, pp. $33-50$

Erasmus L.J., Botha P.M., Kistner A., 1992. Effect of yeast culture supplement on production, rumen fermentation and duodenal nitrogen flow in dairy cows. J. Dairy Sci. 75, 3056-3065

Fallon R.J., Harte F.J., 1987a. The effect of yeast culture inclusion in concentrate diet on calf performance. J. Dairy Sci. 70, 143 (abstr.)

Fallon R.J., Harte F.J., 1987b. Yeast culture in calf rations. In: T.P. Lyons (Editor). Biotechnology in the Feed Industry. Alltech Technical Publications, Nicholasville, Kentucky, pp. 127-136

Garvie E.I., Cole C.B., Fuller D., Hewitt D., 1984. The effect of yoghurt on some components of the gut microflora and on the metabolism of lactose in the rat. J. Appl. Bacteriol. 56, 237-245

Harmon D.L., 1993. Nutritional regulation of postruminal digestive enzymes in ruminants. J. Dairy Sci. 76, 2102-2211

INRA, 1988. Institut National de la Recherche $\Lambda$ gronomique, Alimentation des bovins, ovins, carpins (Ed. R.Jarrige), Paris

Johns J.T., Bergen W.C., 1973. Studies on amino acid uptake by ovine small intestine. J. Nutr.103, $1581-1586$

Kakade M.L., Simons N., Liener I.E., 1969. An evaluation of natura vs. synthetic substrates for measuring the antytriptic activity of soybean samples. Cereal Chem. 46, 518-526

Pusztai A., Grant G., King T.P., Clarcke E.M.W., 1990. Chemical probiosis. In: W. Haresing, D.J.A. Cole (Editors). Recent Advances in Animal Nutrition. Butterworths, London, pp. 47-60

Sivert S.J., Shaver R.D., 1993. Effect of nonfiber carbohydrate level and Aspergillus oryzae fermention exstract on intake, digestion and milk production in lactating dairy cows. J. Anim. Sci. $71,1032-1040$

Skórko-Sajko H., 1993. Evaluation of Yea-Sacc 1026 preparation (in Polish). In: Materials A Divisory Forum, ART Olsztyn, PII Polmarche-Alltech., Poland, pp. 3-27

Wallace R.J., Newbold C.J, 1992. Probiotics for ruminants. In: R. Fuller (Editor). Probiotics the scientific basis, Chapman and Hall, London, pp. 316-353

Williams P.E.V., 1988. Understanding the biochemical mode of action of yeast culture. In: T.P. Lyons (Editor). Biotechnology in the Feed Industry. Alltech Technical Publications, Nicholasville, Kentucky, pp. 127-136

Williams P.E.V., 1989. The use of yeast culture to improve ruminant productivity. In: T.P. Lyons (Editor). Biotechnology in the Feed Industry. Alltech Technical Publications, Nicholasville, Kentucky, pp. 65-84

Williams P.E.V., Newbold C., 1990. Rumen probiosis: The effect of novel microorganisms on rumen fermentation and ruminant productivity. In: W. Haresing, D.J.A. Cole (Editors). Recent Advances in Animal Nutrition. Butterworths, London, pp. 211-225 


\section{STRESZCZENIE}

Zastusowanie drożdży jako dodatku paszowego w żywieniu bydla.

1. Plynne żywe kultury drożdży w żywieniu cieląt

Doświadczenic trwające $73 \mathrm{dni}$ prowadzono na 40 tygodniowych cielętach rasy ncb, podzielonych na 5 grup po 8 sztuk w każđej. Zwierzçta otrzymywały dzicnnic po $8 \mathrm{~kg}$ pcłncgo mleka przez 5 tygodni, następnie $5 \mathrm{~kg} \mathrm{w}$ szóstym, $3 \mathrm{~kg} \mathrm{w}$ siódmym tygodniu doświadczenia przy stałym dostępie do mieszanki pasz treściwych i siana łakkowego. Po 7 tygodniach zwierzęta otrzymywaly jedynic mieszankę treściwą do woli i $0,3-0,4 \mathrm{~kg}$ siana dziennic. Podstawowa dicta dla grupy kontrolncj była przez cały okres doświadczenia uzupetniana surową brzeczkit. a w pozostałych grupach doświadcralnych plynnymi drożlżami Saccharomyces cerevisiae 1026 lub Sacharomy'ces carlsbergensis szczepu piwowarskiego SK-1 lub BS-Bratysława szczepu winiarskiego T-81. Wszystkic szczcpy drożdży stymulowaly amylolityczną i protcolityczną aktywność treści dwunastnicy, jelita cicnkicgo i biodrowego. Przyrosty masy ciała cieląt otrzymujących drożdże szczepu SK-1 i BS-Bratyslawa były wiçkš niż w po\%ostałych grupach. 